\title{
Cued in: honey bee pheromones as information flow and collective decision-making
}

\author{
Tanya PANKIW* \\ Department of Entomology, Texas A\&M University, College Station, TX 77845-2475, USA
}

(Received 28 July 2003; revised 20 November 2003; accepted 15 January 2004)

\begin{abstract}
Recent studies using diverse disciplines ranging from classical behavioral assays to quantitative trait locus mapping, have revealed that chemical communication in honey bees is generally complex. Pheromones that are blends of multiple components are the rule rather than the exception. Subsets of multiple component blends regulate common and different systems. Reviewed are recent studies in pheromone regulation of colony defense, foraging ontogeny, and retinue behavior. Honey bee chemical communication is discussed as an emergent property of a complex system with dynamic properties calling for a complex systems approach of analysis.
\end{abstract}

Apis mellifera / pheromone / chemical communication / social regulation / emergent property / complex system

\section{INTRODUCTION}

The aim of this review is to explore the role of honey bee pheromones in collective decision making and information flow. Relatively recent findings regarding pheromone-regulated behaviors are discussed as examples of information flow and group decision-making. In general, social insect pheromones are classified as releasers or primers. Releaser pheromones stimulate a response instantaneously, comprising a behavioral response mediated by the nervous system. The best-known and characterized releaser responses to honey bee pheromones are stinging and orientation behaviors. Pheromone regulated defensive behavior is a classical mass-action response to a releaser pheromone demonstrating individual and colonylevel decision-making. Primer pheromones change individuals to an altered behavioral repertoire. Change occurs through putative response threshold shifts to different stimuli by physiologically altering reproductive, endocrine and neurosensory systems. Interestingly the honey bee primer pheromones function as releaser and primer pheromones. The fatty acid esters extractable from the surface of larvae, known as brood pheromone, induce the greatest number of known primer responses in honey bees (see Tab. I). Additionally, brood pheromone also releases pollen foraging behavior. Finally, the queen pheromones also elicit a combination of releaser and primer effects. Retinue response of workers to the queen is the releaser effect of queen pheromones, while the primer effects function in the regulation of individual worker and colony-level reproduction.

\section{COLONY DEFENSE COMMUNICATION}

All effective sentinel systems have common characteristics such as rapid and widespread communication of disturbance and recruitment of defenders, coupled with prompt termination after the threat is removed or eliminated. Colony

\footnotetext{
* Corresponding author: t-pankiw@tamu.edu
} 
Table I. Known biological activities of known brood pheromone components.

\begin{tabular}{|c|c|c|}
\hline Compounds & Biological activity & Reference \\
\hline $\begin{array}{l}\text { Methyl linolenate } \\
\text { Methyl linoleate } \\
\text { Methyl oleate } \\
\text { Methyl palmitate }\end{array}$ & $\begin{array}{l}\text { Compounds that trigger cell capping } \\
\text { of pre-pupae }\end{array}$ & (LeConte et al., 1990) \\
\hline $\begin{array}{l}10 \text { components and fewer } \\
\text { present in various ratios and } \\
\text { quantities }\end{array}$ & Communicate sex, caste, and age of larvae & $\begin{array}{l}\text { (Trouiller, 1993; Trouiller et al., } \\
\text { 1994, 1991) }\end{array}$ \\
\hline Methyl stearate & Increases queen cell acceptance & \\
\hline Methyl linoeate & Enhances amount of royal jelly deposited & (LeConte et al.. 1995) \\
\hline Methyl palmitate & $\begin{array}{l}\text { Associated with increased queen larva } \\
\text { weight }\end{array}$ & \\
\hline $\begin{array}{l}\text { Methyl palmitate } \\
\text { Ethyl oleate }\end{array}$ & $\begin{array}{l}\text { Hypopharyngeal gland development } \\
\text { and protein biosynthesis compound }\end{array}$ & (Mohammedi et al., 1996) \\
\hline $\begin{array}{l}\text { Ethyl palmitate } \\
\text { Methyl linolenate }\end{array}$ & $\begin{array}{l}\text { Variable inhibition of worker bee ovary } \\
\text { development }\end{array}$ & (Mohammedi et al., 1998) \\
\hline Methyl oleate & $\begin{array}{l}\text { Attractant-induces mild retinue-like } \\
\text { response }\end{array}$ & (Keeling et al., 2003) \\
\hline \multirow[t]{2}{*}{ 10-component blend } & Foraging ontogeny & $\begin{array}{l}\text { (LeConte et al., 2001; Pankiw and } \\
\text { Page, 2001) }\end{array}$ \\
\hline & Forage choice behavior & (Pankiw and Page, 2001) \\
\hline 10-component blend & $\begin{array}{l}\text { Modulation of worker sucrose response } \\
\text { thresholds }\end{array}$ & (Pankiw and Page, 2001, 2003) \\
\hline
\end{tabular}

defense is a complex combination of behavioral responses partly released and modulated by pheromones. Typically, upon disturbance, bees are alarmed. Alarm behavior is distinguished from defensive behavior by the absence of stinging. Alarmed bees are agitated and assume aggressive postures such as forelegs raised off the substrate, antennae projected forward, and wings and mandibles spread. Alarmed bees may charge toward the source of alarm or alarm pheromones or fly from the nest to locate the source. Once the source of disturbance is located, additional targeting occurs mediated by odors near the target emanating from orienting bees and imbedded stingers. Finally the target is stung, signifying a defensive response. The dissection of behaviors that collectively constitute colony defense has lead to significant insights regarding the roles of individual and combined defensive pheromone components and genomic mapping of quantitative defensive traits loci.

Alarm and defense chemicals are produced in the mandibular gland and sting apparatus of worker bees. Mandibular gland alarm secretions are widespread among arthropods and are believed to be less derived defensive chemistry (Duffield et al., 1984). Mandibular glands of guard- and forager-aged bees produce the alarm substance, 2-heptanone (Kerr et al., 1974). The major defensive compounds include (Z)-11-eicosenol, isopenyl acetate, a blend of low molecular weight alcohols and their respective acetates found in the membranes associated with the stinger. Over 40 compounds have been identified from extracts of the worker sting apparatus (Blum and Fales, 1988). Compounds extractable from the sting gland include precursor, intermediate and final biosynthetic products. About 15 sting gland components release one or some alarm behaviors (Collins and Blum, 1982). The first defensive compound isolated and identified was isopentyl acetate (IPA) (Boch et al., 1962). IPA presented alone elicits more stinging activity than any of the other defensive compounds. IPA also acts as a target-marking pheromone, guiding other defenders to the sting site. The most abundant compound extractable from the 
sting apparatus, (Z)-11-eicosenol, also releases stinging behavior but not to the same degree as IPA. IPA and (Z)-11-eicosenol are synergistic in their natural ratios and as effective in releasing stinging as an equivalent amount of sting apparatus extract (Pickett et al., 1982). The blend of IPA and (Z)-11-eicosenol is active for a longer time than IPA alone, likely because (Z)-11-eicosenol slows the evaporation of IPA (Pickett et al. 1982).

Multiple component pheromones, eliciting multiple or seemingly redundant responses is a recurring theme in studies of honey bee pheromones and suggests a complex system of chemical communication. Most recently Wager and Breed (2000) dissected the roles of 10 alarm pheromone components. They concluded that the principal roles of alarm components are to alert and attract bees to moving predator targets. One or more components may elicit single or multiple responses. For example, the 10 components were used in independent tests for releasing alarm recruitment, flight, and target location behaviors. Few elicited only one measured response, whereas most elicited two or more responses. Hunt et al. (2003) recently discovered a new alarm pheromone component, 3-methyl-2-buten-1-yl (3M2BA), found only in Africanized bees. The novel pheromone recruits Africanized and European defenders alike, is as effective as IPA in recruiting alarm response, and shows some additive recruitment when combined with IPA. The novel pheromone is structurally similar to IPA that may serve as it's precursor and likely explains the similar behavioral responses.

The complexity of alarm pheromone components and defensive response is attributable, in part, to their genetic architecture. Quantitative trait locus (QTL) mapping of quantities of honey bee pheromone components extractable from the sting apparatus has demonstrated amazing complexity (Hunt et al., 1999). A mapping population was produced from hybrid backcrosses of Africanized and European subspecies of honey bees that characteristically show high and low defensive behavior, respectively (Hunt et al., 1999). In general, there was little correlation between extractable quantities of alarm pheromone components and previously mapped defensive behaviors (Hunt et al., 1999; Hunt et al., 1998). Seven independent, putative QTL were identified on five different linkage groups. For the most behaviorally significant component, IPA, four QTL were identified each on a different linkage group. Three loci were identified for n-octanol, and one locus for hexyl acetate, and potentially another for ndecyl acetate (Hunt et al., 1999). Unlinked genetic influence of alarm pheromone production on behavioral response thresholds makes biological sense. In this way, response thresholds to cues for releasing alarm and defensive responses may independently change by natural selection pressure without the cost of greater production or change in pheromone chemistry. These data suggest a dynamic complex system where unlinked component parts of the honey bee defense system are free to recombine and emerge as flexible defensive behavior.

\section{PRIMER-RELEASER PHEROMONES}

Only two social insect primer pheromones have been chemically characterized; brood and queen mandibular gland pheromones. In general, these primer pheromones communicate larval and queen presence, respectively. The effects of primer pheromones are profound. Depending on adult worker response state and social context, primer pheromones may change reproductive, endocrine, and neuro-sensory systems and associated behaviors. Primer pheromones are relatively nonvolatile, acting within a short-volatile space and primarily moving through the colony by inter-individual contact. Primer pheromones change individuals to an altered behavioral repertoire by physiologically altering reproductive, endocrine systems, and neurosensory systems.

\subsection{Brood pheromone (BP)}

The compounds generally known as brood pheromone are a 10-component blend of methyl and ethyl esters of linoleate, linolenate, oleate, palmitate, and stearate (LeConte et al., 1990). The esters are non-volatile. Some are variably unstable; subject to oxidation. Movement is likely facilitated by worker-worker contact. Esters extractable from the surface of larvae, to date, have more biological activity than any other known set of honey bee pheromones (summarized in Tab. I). Brood 
pheromone releases pollen foraging behavior, modulates a neuro-sensory response to sucrose (see Scheiner et al., 2004), and depending on concentration, accelerates or delays the onset of foraging.

Pollen foraging behavior induced by treatment with brood pheromone demonstrates a classic releaser response. Twelve randomly selected colonies pollinating almonds were subjected to pulsed treatments of brood pheromone (Pankiw and Page, 2001). Treatment with brood pheromone and blank glass plates were alternated between colonies in the morning and early afternoon. Colonies receiving BP in the morning received blank control plates in the afternoon and visa versa. One hour after treatment, the number of pollen and non-pollen foragers entering the colonies was counted for a 5-minute period. Treatment plates were removed when entrance counts were completed. One hour after treatment plate removal, entrance counts were conducted. Two hours later reverse treatments were applied. The same series of events took place. One hour after treatment, entrance counts were conducted, and treatments were removed. Entrance counts were conducted once more 1 hour after removal.

The ratio of pollen to non-pollen foragers entering BP treated colonies was significantly greater than controls one hour after applying the pheromone and decreased to control levels one hour after removal of the pheromone (Pankiw and Page, 2001). A similar result was replicated in the afternoon when treatments were reversed. The history of the responding pollen foragers was unknown. They may have originated from a pool of inactive pollen foragers, and/or were young bees newly recruited into foraging. The number of nectar foragers between pheromone treated and control colonies did not change, so role switching could not account for the source of new bees. We concluded that brood pheromone increased the pollen foraging stimulus environment and released these bees into a specific foraging role. Once the brood pheromone stimulus was removed, these bees ceased to forage. This is a classic releaser response to a pheromone stimulus. The foraging releaser response to brood pheromone is closely associated with foraging priming response.

LeConte et al. (2001) treated colonies with the 10-component blend of synthetic brood pheromone. They found that workers in hives treated with 6200 larval equivalents (LEq) of synthetic brood pheromone delayed foraging relative to workers in untreated control colonies with no brood. As part of the same study, they treated some colonies with a "low dose" of BP (620 LEq) and some with a "high dose" (6200 LEq). Bees reared in colonies with low doses of BP foraged at significantly younger ages than bees reared with high doses. Modulation of sucrose response thresholds by brood pheromone is also dose dependent (Pankiw and Page, 2001). Low amounts of brood pheromone decrease sucrose response thresholds in caged bees (Pankiw and Page, 2001). Low sucrose response thresholds are associated with pollen foraging and early age of first foraging (Pankiw, 2003). High amounts of brood pheromone increase sucrose response thresholds in caged bees (Pankiw and Page, 2001). High sucrose response thresholds are associated with nectar foraging and later ages of first foraging (Pankiw, 2003). Brood pheromone appears to change individuals and their behavioral development trajectories; a primer effect. The nature of developmental trajectory itself may be examined by manipulating pheromone environment to reveal a complex dynamic system.

I used brood pheromone to change the foraging stimulus environment of colonies and survival analysis statistics to test the foraging probability predictions of foraging ontogeny as a continuum or a discrete developmental switch (Pankiw submitted). Foraging ontogeny as a continuum makes several predictions; (1) as individuals age they become progressively more responsive to stimuli that release foraging behavior displayed as combining foraging probability factors, and (2) an increase in stimulus environment should recruit successively younger bees resulting in disproportionate probabilities for foraging. Foraging ontogeny as a discrete developmental switch predicts that (1) probability to forage is proportional, independent of change in stimulus environment, and (2) individuals develop competence to forage resulting in overall proportionate probabilities to forage.

Into twelve colonies were placed three distinguishing, paint-marked cohorts of bees; 1-3 days, 5-7 days, and 10-13 days. Colonies were equalized for number of bees, amount of 


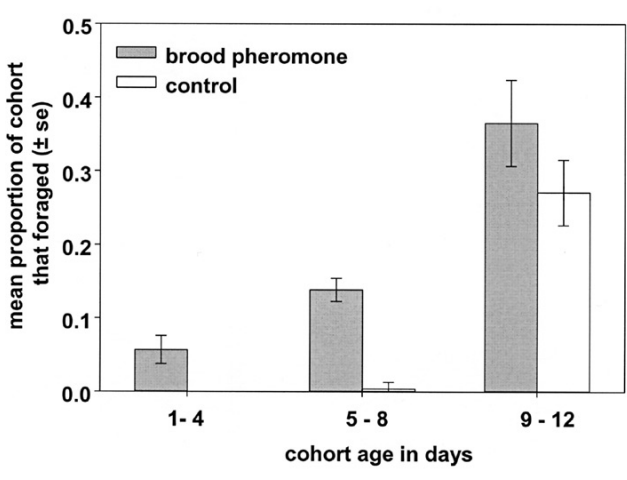

Figure 1. Mean proportion of each cohort that foraged in brood pheromone and control colonies. The middle cohort, 5-8 days, was most likely to forage due to brood pheromone environment whereas, overall probability to forage increased with age.

food stores, brood and, empty space. The colonies were observed daily upon first introducing the oldest cohort. Six colonies were treated with 2000 LEq of synthetic BP and six were controls. Treatments were applied when the youngest cohort was three days old, prior to the onset of foraging by the oldest cohort. Returning paint-marked foragers were captured at the entrances of each colony. Colony entrances were blocked with wire mesh for 15minute intervals, repeatedly once every hour for three hours, beginning one hour after treatment. Foragers were individually captured in small cylindrical wire cages.

Survival analysis was used to analyze age of first foraging data. Survival analysis is a class of statistical methods for studying the occurrence and timing of events. Cox proportional hazards regression analysis is a method for modeling time-to-event data in the presence of censored cases. In this study, the event was foraging. Censored cases were assumed to be nonforaging bees that were collected inside the colony in the termination census. Continuous time was chronological age, and the cohorts were treated as a categorical variable. An assumption of Cox proportional hazards regression analysis is that hazards are parallel (Allison, 1998). Lack of proportion is obvious from the histogram of Figure 1. If foraging probabilities were proportional then the bars between treatments in Figure 1 would appear evenly stepped.
When probabilities are not proportional it is appropriate to continue analysis with an extended Cox regression model (Allison, 1998; SAS, 2000). In a complete model of extended Cox regression analysis including treatment, colony pair, and cohort, the variable colony pair had no significant effect on age of first foraging $\left(X_{2}^{2}=\right.$ $0.1, P>0.05)$, therefore data were pooled for subsequent analysis and visual display of results (Allison, 1998). Treatment had a significant effect on age of first foraging $\left(X_{1}^{2}=76.4\right.$, $P<0.0001$; Fig. 1). The statistic, $\mathrm{e}^{\mathrm{a}}$ was 1.9 , meaning that bees in colonies treated with brood pheromone were almost 2 times more likely to forage during the experimental period than control bees. Cohort also significantly affected age of first foraging $\left(X_{2}^{2}=21.7, P<\right.$ $\left.0.0001 ; \mathrm{e}^{\hat{a}}=0.6\right)$. This means that with each successive increase in age-cohort, probability to forage increased by $40 \%$. The middle cohort, 5-8 days old, displayed the greatest probability to forage due to brood pheromone environment $\left(\mathrm{e}^{\hat{a}}=31.8, P<0.0001\right)$ compared to the control. Next was the 1-4 day old cohort, ( $\mathrm{e}^{\hat{\mathrm{a}}}=2.1, P<$ $0.05)$, followed by the 9-12 day old cohort, $\left(\mathrm{e}^{\hat{\mathrm{a}}}=0.7, P<0.05\right)$.

Brood pheromone clearly recruited successively younger bees into foraging and resulted in disproportionate foraging probabilities between high and low stimulus environments (Fig. 1). These results support the hypothesis that foraging ontogeny is a continuum. The middle cohort, bees aged 5-8 days old, were most likely to the forage in a high brood pheromone environment, likely to forage due to brood pheromone environment. However, overall probability to forage increased with age. Several factors may be at work to explain changes in foraging probability due to age and brood pheromone.

Factors that affect foraging probability can be competing or combining with brood pheromone to release foraging. Additionally, combining probability factors have been speculated to be hierarchical (Winston, 1987). As individuals age they may become more responsive to stimuli that release foraging behavior such that foraging factors were competing or combining. In this study brood pheromone was not eliminated as a factor in the oldest cohort $\left(\mathrm{e}^{\beta}>0\right)$. This was interpreted as brood pheromone combining with other, unknown factors that released increasing numbers of bees into foraging 
with age (Allison, 1998). The observed oscillating forging probabilities due to brood pheromone, such that $\mathrm{e}^{\beta}$ was $2.1,31.8$, and 0.7 , from the youngest to oldest cohort, respectively, suggested a shift in the hierarchy of brood pheromone among other, unknown factors. These results suggest that the overall increased probability to forage due to brood pheromone and age supports a view of concurrent combining and hierarchical foraging factors. The system is complex and highly dynamic, changing with environment and over the course of days.

Currently, the pollen foraging specific and the foraging ontogeny responses to brood pheromone are recognized as releaser and primer effects, respectively. The time scale on which the effects are observed is a principal basis for discriminating the releaser and primer effects of BP. The pollen foraging releaser effect of $\mathrm{BP}$ is observed on a time scale of minutes to hours. Effects on foraging ontogeny occur on the time scale of days. The neurophysiological mechanisms that are affected by BP are not known. Clarification at the neurological level will hopefully improve our definition of BP as a releaser and primer pheromone.

Combined, the above studies suggest that esters have profound effects on the onset of foraging that are dose dependent. A relatively low amount of esters induces early foraging and a relatively high amount delays the onset of foraging. Esters are additionally found on queens and adult workers (Keeling et al., 1999; LeConte et al., 1990; Leoncini, 2002). Honey bee esters are emerging as major regulators of individual and colony-level organization. From different combinations of the esters emerge different responses. This suggests a dynamic and complex system.

\subsection{Queen retinue pheromones}

As a releaser pheromone, queen mandibular pheromone (9-keto-2-(E)-decenoic acid, 9hydroxy-2-(E)-decenoic acid (88\% R-(-) and $12 \%$ S-(+), methyl $p$-hydroxybenzoate, and 4hydroxy-3-methoxyphenylethanol (Slessor et al., 1988) elicits retinue behavior characterized by a group of workers that antennate, lick and groom the queen, removing pheromone from her body (Naumann, 1991; Naumann et al., 1991, 1992; Seeley, 1979). Queen mandibular pheromone (QMP) is subsequently circulated throughout the nest via serial worker to worker transmissions. The empirical movement of QMP components was modeled and stands as the only example of quantified information flow in a social insect system (for details see Naumann, 1991; Naumann et al., 1990, 1991, 1992, 1993). The components of QMP are relatively non-volatile, with a small volatile space of about $12 \mathrm{~mm}$ from the source (Kaminski et al., 1990). Retinue response by bees encountering the queen is intimately associated with queen to worker, and subsequent worker to worker physical transmission of QMP throughout the nest. QMP, in part, regulates the timing of colony-level reproduction (swarming). Queen rearing behaviors are inhibited by sufficient amounts of QMP. When the titer of QMP decreases below inhibitory thresholds, workers initiate queen rearing; a primer response. As colonies grow, worker population increases and the amount of QMP reaching individual bees decreases due to a dilution effect and restricted movement due to crowding congestion (Naumann et al., 1993; Watmough et al., 1998a). Consequently, workers are released from the inhibitory effects of QMP on queen rearing and begin to rear queens in preparation for colony-level reproduction, also referred to as swarming (Watmough, 1997; Watmough et al., 1998b). The amount of QMP in circulation in the nest clearly has profound effects on individual and group-level reproduction.

There is a genotypic component to QMP induced retinue response (Pankiw et al., 2000; Pankiw et al., 1994). Strains of bees were selected for high and low retinue response to QMP in a laboratory retinue bioassay (Pankiw et al., 2000). Bees selected for high retinue response to QMP were more likely to engage in queen rearing behaviors than low retinue responding bees when fostered at the same time in the same queenless colony (Pankiw, 1997; Pankiw et al., 2000). Retinue response to QMP is dose dependent, such that there is a genotypic constraint on response. Bees selected for high retinue response showed higher responses to QMP for all doses compared to the low strain (Pankiw, 1997). Interestingly, high and low strain QMP responding bees did not show differential retinue response to a queen when reared at the same time in the same colony 
(Pankiw et al., 1995). This suggested that cues additional to QMP also induced retinue response.

Keeling et al. (2003) used the well-established laboratory retinue bioassay and a low strain of QMP responding bees to find additional retinue pheromone components. The additional compounds were extractable from the surface of queens and include: methyl oleate, coniferyl alcohol, palmityl alcohol and linolenic acid. QMP plus the four additional components show retinue response most similar to a whole queen extract (Keeling et al., 2003). Primer functions associated with these new retinue compounds have not been reported. The new retinue compounds do not affect worker ovary development, nor did a combination of QMP and the four new components additionally or synergistically inhibit ovary development (Hoover et al., 2003).

The evolutionary and functional significance, if any, of nine retinue chemicals extractable from two different areas of a queen's body is enigmatic. Clearly, retinue response is critical to attracting workers to the queen. The releaser pheromones place workers in direct contact with queen reproduction regulating pheromones and facilitate the movement of these chemicals in the nest to communicate queen presence. A chance mutation causing loss of QMP retinue function could potentially disrupt the timing of QMP swarming regulation. Additionally, nine retinue compounds suggests complexity of chemical communication configured by natural selection. The evolution of fail-safe backup systems may explain seemingly functional redundancy, suggest an evolutionary history of communication failure, or an interplay of chemical communication of a dynamic complex system with emergent properties.

\section{CONCLUSION}

Social insect chemical communication remains a frontier science. Approximately 50 substances derived from queens, workers, and brood have been identified as having biologically functional roles in colony life. Some may prove to be inactive biosynthetic precursors and degradation products, and undoubtedly, more are yet to be discovered. The current state of knowledge leaves us in an ambiguous position to ascertain the evolution of chemical communication in the honey bee. Multicomponent blends that are multi-functional primers and releasers have emerged as the rule rather than the exception.

Are responses to pheromones an emergent property of a complex system? Emergence recalls the adage that, a whole is more than the sum of its parts. That is, complex systems demonstrate properties, often called "emergent properties" that are not verified by the parts, and cannot be predicted a priori even with complete understanding of the individual parts. An emergent property is a property that a collection or complex system has, but that individual members do not have. For example, the taste of saltiness is a property of salt, but does not mean that it is also a property of sodium and chlorine, the two elements that comprise salt. Saltiness is an emergent property of salt. Water can conduct electricity even though neither of its component molecules, hydrogen and oxygen, is conductive. Thus the conductive property of water is emergent. The pressure of a volume of gas is emergent from the molecules of gas in the container; none of the individual molecules can be said to have "pressure".

Honey bee pheromones also display emergent properties. Only the complete blend of all nine retinue components elicits full retinue response in worker bees. 9-keto-2-(E)-decenoic acid (ODA) is one component of queen retinue pheromone that modulates worker endocrine function. Queen retinue pheromone is additionally composed of ethyl oleate and palimitate, none of which are known to have singular or combined biological activity. Retinue response is an emergent property of all nine components. The regulation of the timing of colony swarming, is in part, an emergent property of the nine-component blend of queen retinue pheromone. Ethyl palmitate and methyl linolenate of brood pheromone modulate worker endocrine function, but when combined with methyl linoleate and oleate in the correct ratios and quantities, this combination cues cell capping of pre-pupae. Cell capping behavior is an emergent property of the chemical complex; methyl palmitate, linolenate, linoleate and oleate. Honey bee chemical communication is clearly a complex system with emergent properties. Thinking about pheromones using 
a complex systems approach may be useful as a general method for analyzing how pheromone systems function and are integrated at the colony-level. Behavioral, genetic and neurophysiological analyses will need to take into account individual and emergent properties of pheromone components for a more complete understanding of pheromone biology.

\section{ACKNOWLEDGEMENT}

The Texas Legislative Honey Bee Initiative supported the writing of this manuscript.

Résumé - Les phéromones de l'Abeille domestique comme flux d'information et prise de décision collective. Le comportement régulé par les phéromones est un exemple de flux d'information et de prise de décision. Les phéromones sont des substances chimiques de communication et, comme telles, elles véhiculent des informations concernant un membre d'une espèce aux autres membres de la même espèce. Les propriétés physiques des phéromones véhiculent déjà de l'information, où les concentrations diminuent dans le temps et dans l'espace à partir du point d'émission. Les phéromones peuvent être volatiles et voyager à travers l'espace ou non volatiles et être transmises par contact entre ouvrières. La sélection naturelle a façonné les phéromones de façon à ce que les substances chimiques qui communiquent l'alarme et la défense soient des substances à recrutement de masse qui sont volatiles et se dissipent rapidement après l'émission. La production de phéromones de défense et la réaction de défense sont des caractères non génétiquement liés. Ceci est logique du point de vue biologique parce que les seuils de réponse à des signaux, qui déclenchent des réactions d'alarme et de défense, et la chimie des phéromones peuvent varier indépendamment sans imposer aux deux systèmes des coûts concomitants. La phéromone royale à l'origine de la formation de la cour comprend un mélange de neuf substances provenant des glandes mandibulaires et de la surface de la reine. Seuls les composants mandibulaires régulent le développement ovarien des ouvrières. Pourtant le mélange total des neuf substances est nécessaire pour obtenir une réaction complète de cour. Singulièrement, certains composés ne semblent pas réguler des fonctions de phéromones incitatrices ni de phéromones modificatrices. Les esters que l'on peut extraire de la surface des larves régulent, à ce jour, le plus grand nombre de comportements. L'activité biologique de certains composants est singulièrement faible ou absente. Une collection sans précédent d'activités de d'incitation et de modification émerge des différentes combinaisons des 10 esters larvaires.
On a à ce jour identifié environ 50 substances, issues des reines, des ouvrières et du couvain, qui jouent des rôles fonctionnels dans la vie de la colonie. Les mélanges à composés multiples qui sont des phéromones incitatrices ou modificatrices multi-fonctions sont plutôt la règle que l'exception. Les réponses aux phéromones au niveau de l'individu et de la colonie présentent les caractéristiques d'une propriété émergente des systèmes complexes. L'émergence rappelle l'adage selon lequel le tout est plus que la somme des parties. Les phéromones de l'Abeille domestique répondent tout à fait à cette description. Les systèmes complexes manifestent des propriétés, souvent appelées "propriétés émergentes », qui ne sont pas confirmées par les parties et ne peuvent être prédites a priori même avec une compréhension totale de chacune des parties. Une propriété émergente est une propriété d'un ensemble ou d'un système complexe que les membres ou les composants pris individuellement n'ont pas. La biologie des phéromones de l'Abeille domestique présentent manifestement des propriétés émergentes d'un système complexe ; elle bénéficierait d'une analyse utilisant l'approche des systèmes complexes et d'un effort continu en vue de la découverte d'autres phéromones.

Apis mellifera / phéromone / communication chimique / régulation sociale / propriété émergente / système complexe

\section{Zusammenfassung - Einordnung: Pheromone} der Honigbienen zum Informationstransfer und als kollektive Entscheidungsträger. Pheromonbestimmtes Verhalten ist ein klares Beispiel für Prozesse der Weitergabe von Information und der Entscheidungsfindung. Pheromone sind chemische Substanzen, die der Kommunikation dienen und Information von einem Mitglied einer Art zu anderen Mitgliedern derselben Art übermitteln. Bereits die physikalischen Eigenschaften der Pheromone übermitteln Information, da die Konzentrationen vom Ort des Freisetzens über die Distanz und die Zeit abnehmen. Pheromone können flüchtig oder nicht flüchtig sein, sie können über den Luftraum oder über Kontakt als Übertragung von Arbeiterin zu Arbeiterin verbreitet werden. Die natürliche Selektion hat Pheromone so gestaltet, dass Substanzen, die als Kommunikation von Alarm und Verteidigung eine Massenaktivierung benötigen, leichtflüchtig sind und sich schnell nach ihrer Emission verteilen. Die Produktion von Pheromonen zur Verteidigung und ihre Beantwortung sind genetisch unabhängige Eigenschaften. Das ergibt einen biologischen Sinn, weil sich die Schwelle zur Verteidigungsreaktion auf den alarmauslösenden Reiz und die Struktur der Pheromone unabhängig voneinander ändern könnten ohne beiden Systemen gleichzeitig Kosten aufzubürden.

Das Königinnenpheromon für den Hofstaat besteht aus einer Mischung von neun Komponenten, die von den Mandibeldrüsen und der Oberfläche der 
Königinnen stammen. Die Komponenten der Mandibeldrüse sind ausreichend, um eine Regulierung der Entwicklung der Eierstöcke der Arbeiterinnen zu bewirken. Zur vollständigen Hofstaatbildung ist aber die volle neun-Komponentenmischung notwendig. Einige der Komponenten scheinen für sich allein weder als Primer noch als Auslöserpheromon eine Wirkung zu zeigen.

Die größte Anzahl verschiedener Verhaltensweisen wird wohl von extrahierbaren Estern von der Larvenoberfläche reguliert. Für sich allein zeigen die meisten Komponenten keine oder nur geringe biologische Aktivität. Ausgehend von verschiedenen Kombinationen von 10 larvalen Estern gibt es ein bisher beispiellos großes Angebot von Auslöserund Primeraktivitäten.

Etwa 50 Substanzen von Königinnen, Arbeiterinnen und Brut mit funktionaler Bedeutung im Volksleben sind bis jetzt identifiziert worden. Mischungen aus vielen Komponenten, also multifunktionale Primer und Auslöser sind eher die Regel als die Ausnahme. Individuelle Reaktionen auf Pheromone und Reaktionen auf Volksebene weisen die für komplexe Systeme typischen emergenten Eigenschaften auf, diese sind ein Beleg für das Sprichwort, nach dem das Ganze mehr ist als die Summe seiner Teile. Für Honigbienen trifft diese Beschreibung sehr deutlich zu. Emergente Eigenschaften komplexer Systeme sind dadurch gekennzeichnet, dass ihre Einzelbestandteile oft nicht genau belegt sind, und dass die Gesamteigenschaften des Systems auch dann nicht a priori vorhergesagt werden können, wenn die Einzelteile vollständig verstanden wurden. Hierbei sind diese Eigenschaften von Ansammlung oder komplexer Systeme sind nicht schon Eigenschaften der Einzelteile. Die Biologie der Honigbienenpheromone ist deutlich durch Züge von emergenten Eigenschaften komplexer Systeme bestimmt, ihr Verständnis würde dementsprechend von einem auf der Analyse komplexer Systeme beruhenden Untersuchungsansatz sowie der fortdauernden Bemühung um die Aufdeckung weiterer Pheromone profitieren.

Apis mellifera / Pheromone / chemische Kommunikation / soziale Regulation / emergente Eigenschaften / komplexe Systeme

\section{REFERENCES}

Allison P.D. (1998) Survival Analysis Using the SAS System. A Practical Guide.: SAS Institute Inc., Cary, NC.

Blum M.S., Fales H.M. (1988) Eclectic chemiosociality of the honeybee: a wealth of behaviors, pheromones, and exocrine glands, J. Chem. Ecol. 14, 2099-2107.

Boch R., Shearer D.A., Stone B.C. (1962) Identification of iso-amyl acetate as an active component in the sting pheromone of the honey bee, Nature 195, 1018-1020.
Collins A.M., Blum M.S. (1982) Bioassay of compounds derived from the honeybee sting, J. Chem. Ecol. 8, 463-470.

Duffield R.M., Wheeler J.W., Eickwort G.C. (1984) Sociochemicals of bees, in: Bell W.J., Cardé R.T. (Eds.), Chemical Ecology of Insects, Sunderland, Massachusetts, Sinauer Associates.

Hoover S.E.R., Keeling C.I., Winston M.L., Slessor K.N. (2003) The effect of queen pheromones on worker honey bee ovary development, Naturwissenschaften 90, 477-480.

Hunt G.E., Collins A.M., Rivera R., Page R.E., Guzman-Novoa E. (1999) Quantitative trait loci influencing honeybee alarm pheromone levels, J. Hered. 90, 585-589.

Hunt G.J., Guzman-Novoa E., Fondrk M.K., Page R.E. (1998) Quantitative trait loci for honey bee stinging behavior and body size, Genetics 148, 1203-1213.

Hunt G.J., Wood K.V., Guzman-Novoa E., Lee H.D., Rothwell A.P., Bonham C.C. (2003) Discovery of 3-methyl-2-buten-1-yl acetate, a new alarm component in the sting apparatus of Africanized honeybees, J. Chem. Ecol. 29, 453-463.

Kaminski L.-A., Slessor K.N., Winston M.L., Hay N.W., Borden J.H. (1990) Honey bee response to queen mandibular pheromone in laboratory bioassays, J. Chem. Ecol. 16, 841-850.

Keeling C.I., Slessor K.N., Winston M.L. (1999) The essence of royalty, the honey bee queen's pheromone arsenal, in: Proc. XXXVI Apimondia Congr. Vancouver, British Columbia, Canada, p. 309

Keeling C.I., Slessor K.N., Higo H.A., Winston M.L. (2003) New components of the honey bee (Apis mellifera L.) queen retinue pheromone, Proc. Natl. Acad. Sci. 100, 14486-14491.

Kerr W.E., Blum M.S., Pisani J.F., Stort A.C. (1974) Correlation between amounts of 2-Heptanone and iso-amyl acetate in honeybees and their aggressive behaviour, J. Apic. Res. 13, 173-176.

LeConte Y., Sreng L., Poitout S.H. (1995) Brood pheromone can modulate the feeding behavior of Apis mellifera workers (Hymenoptera: Apidae), J. Econ. Entomol. 88, 798-804.

LeConte Y., Arnold G., Trouiller J., Masson C. (1990) Identification of a brood pheromone in honeybees, Naturwissenschaften 81, 462-465.

LeConte Y., Mohammedi A., Robinson G.E. (2001) Primer effects of a brood pheromone on honeybee behavioural development, Proc. R. Soc. London B 268, 1-6.

Leoncini I. (2002) Phéromones et régulation sociale chez l'abeille, Apis mellifera L. : identification d'un inhibiteur du développement comportemental des ouvrières, Thèse Doctorat, Paris, Institut National Agronomique.

Mohammedi A., Crauser D., Paris A., Le Conte Y. (1996) Effect of a brood pheromone on honeybee hypopharyngeal glands, C.R. Acad. Sci. Paris, Sci. Vie 319, 769-772. 
Mohammedi A.P., Crauser D., Le Conte Y. (1998) Effect of aliphatic esters on ovary development of queenless bees (Apis mellifera L.), Naturwissenschaften $85,455-458$.

Naumann K. (1991) Grooming behaviors and the translocation of queen mandibular gland pheromone on worker honey bees (Apis mellifera L), Apidologie 22, 523-531.

Naumann K., Winston M.L., Wyborn M.H., Slessor K.N. (1990) Effects of synthetic honey bee (Hymenoptera: Apidae) queen mandibular-gland pheromone on workers in packages, J. Econ. Entomol. 83, 1271-1275.

Naumann K., Winston M.L., Slessor K.N., Prestwich G.D., Webster F.X. (1991) Production and transmission of honey bee queen (Apis mellifera L.) mandibular pheromone, Behav. Ecol. Sociobiol. 29, 321-332.

Naumann K., Winston M.L., Slessor K.N., Prestwich G.D., Latli B. (1992) Intra-nest transmission of aromatic honey bee queen mandibular gland pheromone components: movement as a unit, Can. Entomol. 124, 917-934.

Naumann K., Winston M.L., Slessor K.N. (1993) Movement of honey bee (Apis mellifera L.) queen mandibular gland pheromone in populous and unpopulous colonies, J. Insect Behav. 6, 211-223.

Pankiw T. (1997) Queen rearing by high and low queen mandibular pheromone responding workers, Can. Entomol. 129, 679-690.

Pankiw T. (2003) Directional change in a suite of foraging behaviors in tropical and temperate evolved honey bees (Apis mellifera L.), Behav. Ecol. Sociobiol. 54, 458-464.

Pankiw T., Page R.E. (2001) Brood pheromone modulates sucrose response thresholds in honeybees (Apis mellifera L.), Behav. Ecol. Sociobiol. 49, 206-213.

Pankiw T., Page R.E. (2003) Effect of pheromones, hormones and, handling on sucrose response thresholds of honey bees (Apis mellifera L.), J. Comp. Physiol. A 188, 675-684.

Pankiw T., Winston M.L., Slessor K.N. (1994) Variation in worker responses to honey bee (Apis mellifera L.) queen mandibular pheromone, J. Insect Behav. 1, 1-15.

Pankiw T., Winston M.L., Slessor K.N. (1995) Queen attendance behavior of worker honey bees (Apis mellifera L.) that are high and low responders to queen mandibular pheromone, Insectes Soc. 42, 371-378.
Pankiw T., Winston M.L., Fondrk M.K., Slessor K.N. (2000) Selection on worker honey bee responses to queen pheromone (Apis mellifera L.), Naturwissenschaften 87, 487-490.

Pickett J.A., Williams I.H., Smith M.C., Martin A.P. (1982) (Z)-11-eicosen-1-ol, an important new pheromonal component from the sting of the honey bee Apis mellifera L, J. Chem. Ecol. 8, 163-176.

SAS (2000) The SAS System Version 8.01, Cary, NC: SAS Institute Inc.

Scheiner R., Page R.E., Erber J., Sucrose responsiveness and behavioral plasticity in honey bees (Apis mellifera), Apidologie 35, 133-142.

Seeley T.D. (1979) Queen substance dispersal by messenger workers in honey bee colonies, Behav. Ecol. Sociobiol. 5, 391-415.

Slessor K.N., Kaminski L.-A., King G.G.S., Borden J.H., Winston M.L. (1988) Semiochemical basis of the retinue response to queen honey bees, Nature 332, 354-356.

Trouiller J. (1993) La communication chimique interet intraspécifique chez l'abeille, Thèse Doctorat, Université Paris.

Trouiller J., Arnold G., Chappe B., LeConte Y., Masson C. (1991) Temporal pheromonal and kairomonal secretion in the brood of honeybees, Naturwissenschaften 78, 368-370.

Trouiller J., Arnold G., Chappe B., LeConte Y., Billion A., Masson C. (1994) The kairomonal esters attractive to the Varroa jacobsoni mite in the queen brood, Apidologie 25, 314-321.

Wager B.R., Breed M.D. (2000) Does honey bee sting alarm pheromone give orientation information to defensive bees? Ann. Entomol Soc. Am. 93, 1329-1332.

Watmough J. (1997) A general model of pheromone transmission within honey bee hives, J. Theor. Biol. 189, 159-170.

Watmough J., Winston M., Slessor K. (1998a) Distinguishing the effects of dilution and restricted movement on the intra-nest transmission of honey-bee queen pheromones, Bull. Math. Biol. 60, 307-327.

Watmough J., Winston M.L., Slessor K.N. (1998b) Distinguishing the effects of dilution and restricted movement on the intra-nest transmission of honey-bee queen pheromones, Bull. Math. Biol. 60, 307-327.

Winston M.L. (1987) The biology of the Honey Bee, Harvard University Press, Cambridge, MA. 